\title{
Analysis of Strategy Implementation on Land and Building Tax Payment Via GoBills (Gojek) in New Normal
}

\author{
Sailawati*, Kristin Wulansari \\ Politeknik Negeri Samarinda \\ Samarinda, Indonesia \\ *@polnes.ac.id
}

\begin{abstract}
The COVID-19 pandemic is not only a health crisis of immense proportion, but it is also an imminent restructuring of the global economy. The impact of the COVID-19 pandemic is extensive and has presented enormous challenges to the world as a whole. A full economic recovery from the Covid-19 is unlikely. The governments must build resilience and lead in this time of crisis to a new phase "new normal" in the COVID-19 pandemic. The purpose of this research was to analysis of strategy implementation on land and building tax payment via gobills use GoPay (gojek) for improving public government performance in the Local Revenue Agency of Samarinda in new normal. This research used a case study qualitative method. The research was conducted by analysing the organization's internal and external environment, which was then incorporated into the SWOT Matrix (Strength, Weakness, Opportunity, Threat), Grand Strategy Matrix, and SPACE Matrix (Strategic Position and Action Evaluation). To collect data, this research used interview techniques, documentation, observation, and literature study. The result of this research showed that the strategy implementation on land and building tax payment via gobills (gojek) was effective and efficient towards achieving organizational goals in new normal. The result also showed that the factor of leadership was of most importance, leadership qualities of The Local Revenue Agency head were identified as the most critical and influential actor in improving organization performance because the leader has to adapt and manage the changes brought by the job, all the roles, responsibilities, and protect the health system of the employee with social distancing guidelines in new normal.
\end{abstract}

Keywords-land and building tax payment, GoPay (Gojek), SWOT matrix, grand strategy matrix, SPACE matrix, leadership quality

\section{INTRODUCTION}

At this time, the Corona Virus Disease-19 (Covid-19) outbreak which has spread, and infected humans is fast becoming a problem that has been highlighted by many parts of the world. The Covid-19 pandemic has not only threatened human health, but has also affected the global economic downturn [1]. Where the shock of the impact of the Covid-19 pandemic is also very pronounced in the ranks of government, where access to public services is faced with the challenge of maintaining excellent public service quality, but on the other hand, we must also pay attention to the safety aspects of service providers and users through the application of social distancing and physical distancing [2].

The Covid-19 pandemic has brought a new life order, namely the new normal era. Where various protocols in undergoing the new normal era have been prepared by the government, including in the bureaucratic structure to provide public services. This makes the organization faced with the conditions of organizational reform, namely adjustment through a process of change in the new normal era, so that a model of bureaucratic change is needed that is able to answer challenges, in the bureaucracy it must optimize the use of technology, information and communication in all matters in the government sector [3]. Drucker states that several demands for organizational reform according to the theory of organizational change can come from internal conditions, namely leadership, resources, organizational structure, etc. and external conditions, namely innovation based on process needs, changes in industrial structure or market structure, demographics, changes in perceptions, etc.

In this crisis condition, the government needs to take a solution to overcome the economic issue which is affected by the Covid-19 pandemic, especially the taxation sector. For example, is the relaxation of the income tax and VAT refunds are extremely effective and appropriate to tackle the impact of the Covid-19 pandemic on the Indonesian economy [4]. Another way is not about reducing the total of payment but give an alternative payment method, namely an electronic system [5].

In this case the limited space for movement due to following health protocols and the demands of the community that their rights as citizens to be served have made the Head of the Local Revenue Agency of Samarinda determine the provision of public services through electronic services. The transformation of the manual service model which is characterized by face-to-face services must move to electronics 
by utilizing technology applications in order to optimize the provision of public services to the community, where the strategy taken is to determine online payments using the Gojek application on the Gobills menu.

The novelty of this study is focusing on the regional tax meanwhile the previous studies mostly focus on the central tax. Furthermore, this study highlights the Gojek application as the tools to pay the land and building tax. Another interesting of this research is using some tools analysis, namely the SWOT Matrix, Grand Strategy Matrix, and SPADE matrix.

This paper aims to review changes in the bureaucracy in the new normal era by analysing the organization's internal and external environment, which was then incorporated into the SWOT, Grand Strategy Matrix, and SPACE Matrix. Bureaucratic changes also require creative ideas that are developed through an innovation in public services so that public services continue to run well, without obstacles even in the conditions of the Covid-19 pandemic. Managing bureaucratic change and innovation is strongly influenced by leadership factors. Therefore, this paper also examines the importance of transformative leadership in order to produce change and innovation in the bureaucracy.

\section{LITERATURE REVIEW}

The continuity of the development of a government, both central and regional, is vital for the attainment of public welfare. One source of this sustainability is the availability of resources that support regional economic development. One of the revenue sources capable of supporting this development is Local Own-Source Revenue.

Since the implementation of regional autonomy in each government, especially district and urban district governments, this policy has opened up opportunities for regions to manage themselves more freely and at the same time challenges for regions to explore the potential of their regional resources, because land and building tax has been transferred to the regions.

Exploring the potential for regional resources in selffinancing is something that must be done, so that the optimization of regional revenue sources [6], especially the United Nations, needs to be pursued due to the conditions of the Covid-19 pandemic. This made the Local Revenue Agency of Samarinda develop a strategy so that land and building payments could still be made by the community without having to come to the Local Revenue Agency of Samarinda, to minimize the build-up of queues that could increase the spread. from Covid-19.

\section{A. Local Own-Source Revenue}

According to Law Number 33 Year 2004, what is meant by "Local Own-Source Revenue is revenue obtained by the region which is collected based on Regional Regulations in accordance with statutory regulations". Local Own-Source Revenue aims to provide authority to the government to fund the implementation of regional autonomy in accordance with regional potential as a form of decentralization $[7,8]$.

Hertanto and Sriyana conducted research on district/urban district Local Own-Source Revenue sources. From the results of his research it can be concluded that in order to increase Local Own-Source Revenue districts / urban districts in West Java, district / urban district governments need to increase regional economic growth through industrial development in the regions by encouraging increased regional investment in order to optimize regional potential [9].

\section{B. Land and Building Tax}

According to Government Regional Regulation of Samarinda No. 04/2011 concerning Regional Taxes, Rural and Urban Land and Building Taxes are taxes on land and/or buildings that are owned, controlled, and/or used by private persons or entities, except for areas used for plantation business activities. forestry and mining. Earth is the surface of the earth which includes land and inland waters as well as sea in regency areas or cities. Buildings are engineering constructions that are permanently planted or affixed to land and or inland waters and or sea [10].

\section{Strategic Management for Increasing Local Own Revenue}

One of the effective ways in regional development is through the Improvement of Regional Apparatus Performance. According to Wardhono et al stated that the factors that influence the optimization of local tax revenues are institutional factors and local tax management [11]. Meanwhile, Farida and Azman stated that the factors that influence the optimization of restaurant tax collection are low taxpayer awareness, weak supervision, and limited human resources as well as facilities and infrastructure [12].

According to Fred R. David, the notion of strategic management is the art and knowledge of formulating, implementing, and evaluating cross-functional decisions that enable an organization to achieve its goals. Strategic management focuses on integrating management, marketing, finance/accounting, production/operations, research and development, and computer information systems to achieve organizational success. The purpose of strategic management is to exploit and create new and different opportunities for tomorrow; long-term planning, on the other hand, seeks to optimize today's trends for tomorrow. A strategic plan is a company's playing tactic [13].

\section{Go-Pay Transactions for Gobills on the Go-Jek Application}

One of the digital financial products is electronic money or e-money. The Karya Anak Bangsa Application Company or commonly known as Go-Jek is one of the subsidiaries that use this e-money which was previously called Go-Wallet and is now known as Go-pay [14].

Article 1 number 7 of Bank Indonesia Regulation Number 18/40 / PBI / 2016, which is meant by Electronic Wallet, 
hereinafter referred to as Electronic Wallet, is an electronic service for storing data on payment instruments, including payment instruments using cards and/or electronic money, which can also be used. accommodate funds, to make payments [15].

Based on information obtained from the Go-Jek official website, Go-Pay is electronic money that can be used to make financial transactions through the Go-Jek application. Go-Pay is an electronic wallet developed by the Go-Jek company to store Go-Jek credit which can be used to pay for service-related transactions in the Go-Jek application. The existence of this electronic money can make it easier for people to make financial transactions without using cash.

Regarding services that can be done in Go-Pay transactions on the Go-Jek application, there are eleven services provided by the Karya Anak Bangsa Application company that can be done in Go-Pay transactions on the Go-Je application. For more details about the Go-Pay service in the Go-Jek application, see the following figure 1 and explanation:

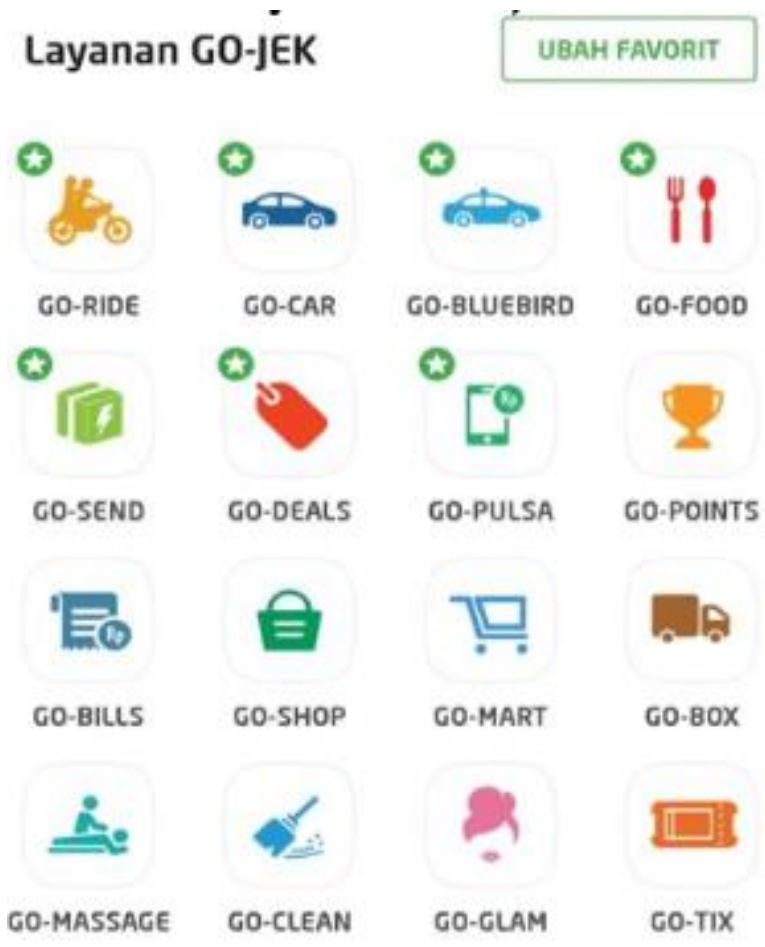

Fig. 1. Gojek application services.

First, Go-Ride: a motorcycle transportation service. Second, Go-Car: transportation service by car. Third, Go-Food: food delivery service. Fourth, Go-Mart or Go-Shop: a service that helps customers shop for various items from various stores. Fifth, Go-Send: instant courier service. Sixth, Go-Box: moving goods service. Seventh, Go-Pulsa: credit purchase service. Eighth, Go-Bills: services for paying various bills such as electricity bills, taxes, etc. using Go-Pay balances. Ninth, Go-Tix: mobile ticketing service. Tenth, Go-Massage, which is a professional health massage service. Eleventh, Go-Clean: professional cleaning services [14].

\section{E. Internal Environment Analysis}

According to Hunger and Wheelen [16], internal strategic factors is identifying the critical strengths and weakness of the company that is likely to determine whether a company will be able to take advantage of opportunities while avoiding threats. These factors include:

- Structure is the way a company organizes communication, authority, and workflow.

- Culture is a pattern of belief, hope, and value-shared from members of the organization.

- Resources are raw materials used by companies for the production of goods and/or services, also in the form of the abilities of their employees and managerial talents.

\section{F. External Environment Analysis}

According to Hunger and Wheelen [16], the external environment consists of variables (opportunities and threats) outside of the organization and not specifically in the shortterm control of top management. External forces can be divided into five broad categories, which are:

- Economic Forces

- Social, Cultural, Demographic, and Natural

- Political, Governmental, and Legal Forces

- Technological Forces

- Competitive Forces

\section{G. SWOT Analysis Matrix}

David explained SWOT matrix is an important matching tool to help managers to develop four types of strategies, namely: SO strategies (strengths- opportunities), WO strategies (weaknesses-opportunities), ST strategies (strengths- threats), and WT strategies (weaknesses-threats) [13] as in table 1.

TABLE I. SWOT MATRIX

\begin{tabular}{|l|l|l|}
\hline Internal Factor & \multicolumn{1}{|c|}{$\begin{array}{c}\text { Strength (s) } \\
\text { Factor Internal } \\
\text { Strength }\end{array}$} & $\begin{array}{c}\frac{\text { Weakness (W) }}{\text { Factor Internal }} \\
\text { Weakness }\end{array}$ \\
\hline $\begin{array}{l}\text { OPPORTUNITIES } \\
(\mathrm{O})\end{array}$ & SO Strategies & WO Strategies \\
\hline THREATS (T) & ST Strategies & WT Strategies \\
\hline
\end{tabular}

\section{H. Grand Strategy Matrix}

David explained that all organizations can be positioned in one of the Grand Strategy Matrix's four strategy quadrants. In this strategy, there are four quadrants, which is divided into two evaluative dimensions, namely: a competitive position (competition), occupying a horizontal line; and market growth (industry), which occupies a vertical line as in figure 2 [13]. 


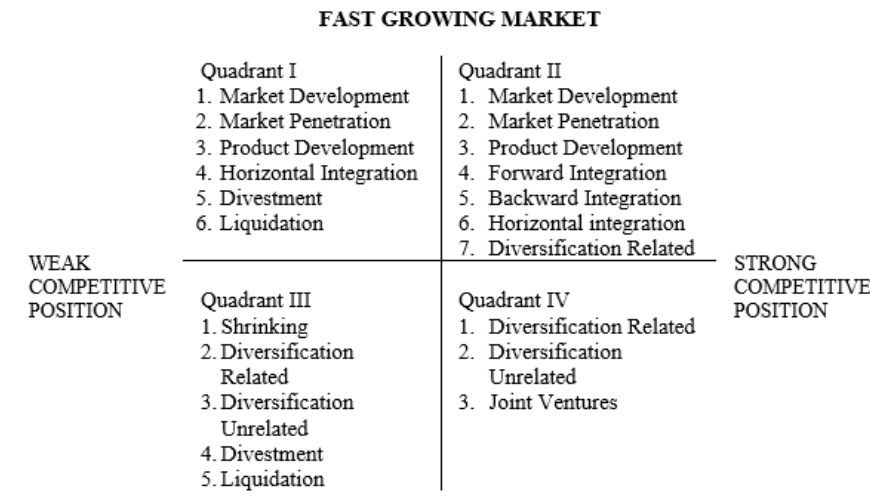

Fig. 2. Grand strategy matrix.

\section{Space Matrix}

This matrix has four quadrants, David (2011:181) described a four-quadrant framework indicates whether aggressive, conservative, defensive, or competitive strategies are most appropriate for a given organization. The axes of the SPACE Matrix represent two internal dimensions (financial position [FP] and competitive position [CP]) and two external dimensions (stability position [SP] and industry position [IP]). These four factors are determinants of what strategies a company will use [13]. Gurbuz [17] explained each of the factors as follows:

- Financial Position (FP): This is an internal dimension that can include return on investment, leverage, liquidity, capital, the risk involved in the business, etc. as key factors.

- Competitive Position (CP): This is an internal dimension that includes market share, product quality, and product life cycles, etc. as key factors.

- Industry Position (IP): This is an external dimension that can include growth and profit potential, financial stability, technological know-how, etc. as key factors.

- Stability Position (SP): This is an external dimension, which can include technological change, rate of inflation, demand variability, the price range of competing products, etc. as key factors.

\section{RESEARCH METHODS}

\section{A. Type of Research}

This research used a case study qualitative method. The research was conducted by analysing the organization's internal and external environment, which was then incorporated into the SWOT Matrix (Strength, Weakness, Opportunity, Threat), Grand Strategy Matrix, and SPACE Matrix (Strategic Position and Action Evaluation).

\section{B. Object of Research}

This research used the interview as the main data in order to obtain specific data that can describe the topic to achieve the objective of the study. The interview was conducted in The Local Revenue Offices.

The source of data that used in this research consists of two sources, namely internal and external data:

- Internal data is data derived from the internal company. In this case, the researcher obtained internal data through interviews with The Local Revenue Office head

- External data is data obtained from outside the company where the research was conducted. The researcher collected external data by observing the taxpayer.

\section{Data Collection Technique}

To collect data, this research used interview techniques, documentation, observation, and literature study.

1) Interview: Setyadin in Gunawan states that the interview is a conversation directed at a particular problem and is a process of verbal questioning.

2) Documentation: Suharsaputra explains that documentation is a written or printed recording of past events, which can be in the form of anecdotal notes, letters, diaries, and documents.

3) Observation: According to Sutrisno Hadi in Sugiyono, observation is a complex process, a process composed of various biological and psychological processes.

4) Literature study: Collect relevant data and information, both from internal and external data such as libraries, document reports, and previous research journals related to this research.

\section{Research Framework}

The research framework as in figure 3 .

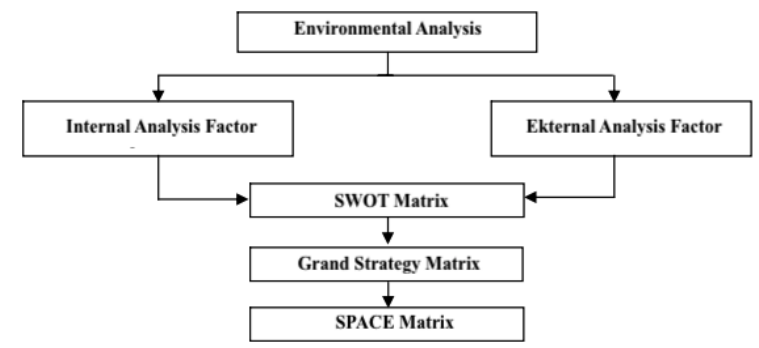

Fig. 3. Research framework.

\section{RESULTS AND DISCUSSION}

\section{A. Environmental Analysis of The Regional Revenue Office of} Samarinda

1) Internal analysis factor: The internal environmental analysis was carried out to observe various internal factors that 
influenced the increase in Land and Building tax payments in the New Normal era at The Local Revenue Office of Samarinda.

The internal factors that become the strengths and weaknesses are as follows:

\section{a) Strength:}

- The existence of Local Regulations that help clear Land and Building tax payments, namely Law No.28 of 2009 concerning Local Taxes and Retributions and Government Regulation Number 65 of 2001 (Article 1 paragraph 1) concerning Local Taxes. Republic of Indonesia, Law Number 18 of 1997 concerning Local Taxes and Retributions,

- The Land and Building tax calculation system is quite clear, namely in the Local Government Regulation of Samarinda Number 4 of 2011 concerning Regional Taxes.

- There is a commitment by the Head of the Local Revenue Agency in improving services to taxpayers.

- Availability of budget for technological innovation from the Local Revenue Agency to support the process of providing excellent service to the community.

- There is a clear division of employee duties by each division in the Local Revenue Agency.

b) Weakness:

- Professional staff resources and in accordance with educational backgrounds are still lacking at the Local Revenue Agency make not all employees technology literate

- Inadequate facilities and infrastructure at the Local Revenue Agency especially related to technology

- Data on potential Land and Building tax receivables is less accurate and complete at Local Revenue Agency because the recording process is still manual

- Weak supervision and legal sanctions, even though it is regulated in Local Regulation No. 6 of 2011 concerning the System, Procedure, and Sanctions for Collecting Local Taxes of the Government of Samarinda.

- Mental attitudes, discipline, and low work motivation of employees in providing excellent service to taxpayers.

TABLE II. INTERNAL ANALYSIS FACTOR

\begin{tabular}{|l|l|l|l|}
\hline \multicolumn{1}{|c|}{ Internal Factors } & Weight & Urgency & Value \\
\hline STRENGTH (S) & & & \\
\hline $\begin{array}{l}\text { The excistense of local regulation that } \\
\text { regulate clear the land and building } \\
\text { taxes psyment }\end{array}$ & 0.17 & 4 & 0.68 \\
\hline $\begin{array}{l}\text { The land and building taxes } \\
\text { calculation system is quite clear }\end{array}$ & 0.17 & 4 & 0.68 \\
\hline
\end{tabular}

Table II. Cont.

\begin{tabular}{|l|l|l|l|}
\hline $\begin{array}{l}\text { There is a commitment by the Head of the } \\
\text { Local Revenue Agency in improving } \\
\text { services }\end{array}$ & 0.12 & 4 & 0.48 \\
\hline $\begin{array}{l}\text { Availability of budget for technological } \\
\text { innovation }\end{array}$ & 0.11 & 4 & 0.44 \\
\hline $\begin{array}{l}\text { There is a clear divisions of employee } \\
\text { duties }\end{array}$ & 0.04 & 2 & 0.08 \\
\hline SUB TOTAL & $\mathbf{0 . 6 1}$ & & $\mathbf{2 . 3 7}$ \\
\hline $\begin{array}{l}\text { Professional staff resources and in } \\
\text { accordance with educational backgrounds } \\
\text { are still lacking }\end{array}$ & 0.07 & 2 & 0.14 \\
\hline Inadequate facilities and infrastructure & 0.08 & 2 & 0.16 \\
\hline $\begin{array}{l}\text { Data on potential land and building taxes } \\
\text { receivable is less accurate and complete }\end{array}$ & 0.09 & 2 & 0.18 \\
\hline Weak supervision and legal sanctions & 0.07 & 2 & 0.14 \\
\hline $\begin{array}{l}\text { Mental attitudes, discipline, and low work } \\
\text { motivation of employees }\end{array}$ & 0.07 & 2 & 0.14 \\
\hline SUB TOTAL & $\mathbf{0 . 3 8}$ & & $\mathbf{0 . 7 6}$ \\
\hline TOTL & $\mathbf{0 . 9 9}$ & & $\mathbf{3 . 1 3}$ \\
\hline
\end{tabular}

2) External analysis factor: External environmental analysis is conducted by evaluating several factors that influence the increase in payments of land and building tax in the Local Revenue Agency of Samarinda.

The external factors that become the opportunities and threats are as follows:

\section{a) Opportunity:}

- The rapid advancement of science makes many innovations that develop in today's era.

- The rapid development of technology has made it easier for people to access information.

- There is involvement with several government agencies, banks, etc., namely the existence of cooperation from other parties in providing services to taxpayers such as cooperation with BRI Bank, Kaltimtara Bank, Pos Indonesia, etc.

b) Threat:

- The Covid-19 pandemic, which does not yet know for sure, will be over, so the Local Revenue Agency must innovate then those services continue.

- Demands for excellent service by taxpayers in the New Normal Era, where the Covid-19 protocol must be considered in providing services.

- The conditions of taxpayers' infrastructure are varied and not all of them can access technology, so there are some taxpayers who find it difficult to provide online services.

\section{TABLE III. EXTERNAL ANALYSIS FACTOR}

\begin{tabular}{|c|l|l|c|}
\hline External Factors & Weight & Urgency & Value \\
\hline OPPORTUNITY $(\boldsymbol{O})$ & & & \\
\hline The rapid advancement of science & 0.20 & 3 & 0.60 \\
\hline The rapid development of technology & 0.20 & 3 & 0.60 \\
\hline $\begin{array}{l}\text { There is involvement with several government } \\
\text { agencies, banks, etc }\end{array}$ & 0.30 & 4 & 1.20 \\
\hline SUB TOTAL & $\mathbf{0 . 7 0}$ & & $\mathbf{2 . 4 0}$ \\
\hline THREAT $(\boldsymbol{T})$ & & & \\
\hline
\end{tabular}


Table III. Cont.

\begin{tabular}{|c|l|l|l|}
\hline $\begin{array}{l}\text { The Covid-19 pandemic, which does not } \\
\text { yet know for sure, will be over }\end{array}$ & 0.15 & 4 & 0.60 \\
\hline $\begin{array}{l}\text { Demands for excellent service by taxpayers } \\
\text { in the New Normal Era }\end{array}$ & 0.07 & 4 & 0.28 \\
\hline $\begin{array}{l}\text { The conditions of taxpayers' infrastructure } \\
\text { are varied and not all of them can access } \\
\text { technology }\end{array}$ & 0.08 & 4 & 0.32 \\
\hline SUB TOTAL & $\mathbf{0 . 3 0}$ & & $\mathbf{1 . 2 0}$ \\
\hline TOTAL & $\mathbf{1 . 0 0}$ & & $\mathbf{3 . 6 0}$ \\
\hline
\end{tabular}

TABLE IV. SWOT MATRIX

\begin{tabular}{|c|c|c|}
\hline External Factor & $\begin{array}{l}\text { Strength (S) } \\
\text { Factor Internal Strength } \\
\text { 1. The excistense of local regulation that regulate } \\
\text { clear the land and building taxes psyment } \\
\text { 2. The land and building taxes calculation system } \\
\text { is quite clear } \\
\text { 3. There is a commitment by the Head of the Local } \\
\text { Revenue Agency in improving services } \\
\text { 4. Availability of budget for technological } \\
\text { innovation } \\
\text { 5. There is a clear divisions of employee duties }\end{array}$ & 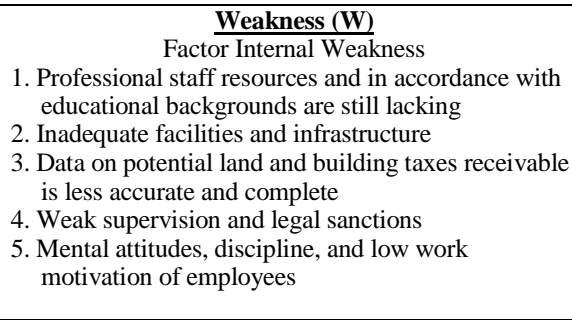 \\
\hline $\begin{array}{l}\text { OPPORTUNITIES (O) } \\
\text { 1. The rapid advancement of science } \\
\text { 2. The rapid development of technology } \\
\text { 3. There is involvement with several } \\
\text { government agencies, banks, etc }\end{array}$ & $\begin{array}{l}\text { SO Strategies } \\
\text { 1. Striving for innovation in land and building tax } \\
\text { payments according to the Covid-19 protocol } \\
\text { 2. Build cooperation networks with various } \\
\text { agencies and banks in paying land and building } \\
\text { taxes } \\
\text { 3. Improve the payment system that makes it easier } \\
\text { for taxpayers (fintech) }\end{array}$ & $\begin{array}{l}\text { WO Strategies } \\
\text { 1. Quality improvement and human resource } \\
\text { development for managers } \\
\text { 2. Improvement of supporting facilities \& } \\
\text { infrastructure } \\
\text { 3. To foster mental attitudes, discipline, work } \\
\text { motivation, and understanding of employees } \\
\text { towards the duties of the civil servants }\end{array}$ \\
\hline $\begin{array}{l}\text { THREATS (T) } \\
\text { 1. The Covid-19 pandemic, which does not } \\
\text { yet know for sure, will be over } \\
\text { 2. Demands for excellent service by } \\
\text { taxpayers in the New Normal Era } \\
\text { 3. The conditions of taxpayers' } \\
\text { infrastructure are varied and not all of them } \\
\text { can access technology }\end{array}$ & $\begin{array}{l}\text { ST Strategies } \\
\text { 1. Performing online services } \\
\text { 2. Providing socialization to the public through } \\
\text { social media regarding online services } \\
\text { 3. Provide online complaints }\end{array}$ & $\begin{array}{l}\text { WT Strategies } \\
\text { 1. Improve the quality of human resources in } \\
\text { technology } \\
\text { 2. Manage employee work from home procedures } \\
\text { clearly } \\
\text { 3. Monitoring employee performance progress }\end{array}$ \\
\hline
\end{tabular}

\section{Grand Strategy Matrix}

TABLE V. GRAND STRATEGY MATRIX

\begin{tabular}{|c|c|c|}
\hline $\begin{array}{l}\text { INTERNAL } \\
\text { EXTERNAL } \\
\text { FACTOR } \\
\end{array}$ & $\begin{array}{l}\text { STRENGTH }(\mathrm{S}) \\
\text { WEIGHTED } \\
\text { VALUE }: 2.37\end{array}$ & $\begin{array}{l}\text { WEAKNESS }(\mathrm{W}) \\
\text { WEIGHTED } \\
\text { VALUE : } 0.76\end{array}$ \\
\hline $\begin{array}{l}\text { OPPORTUNITIES (O) } \\
\text { WEIGHTED VALUE : } 2.40\end{array}$ & $\begin{array}{l}\text { SO - STRATEGY } \\
4.77\end{array}$ & $\begin{array}{l}\text { WO } \\
\text { STRATEGY } \\
3.16 \\
\end{array}$ \\
\hline $\begin{array}{l}\text { THREATS }(\mathrm{T}) \\
\text { WEIGHTED VALUE : } 1.20\end{array}$ & $\begin{array}{l}\text { ST - STRATEGY } \\
3.57\end{array}$ & $\begin{array}{l}\text { WT } \\
\text { STRATEGY } \\
1.96 \\
\end{array}$ \\
\hline
\end{tabular}

The formulation of a strategy that can be considered effective and efficient (grand strategy) in improving the performance of the Local Revenue Agency of Samarinda is SO-Strategy with a total of 4.77 (table 5). Namely a strategy by using the internal strength that is owned to be utilized to seize existing external opportunities, or also often referred to as an aggressive strategy. This means that the potential advantages possessed, namely in the form of existing internal strength factors, are managed in such a way as to become a driving force (move of rule) in order to seize existing opportunities.

\section{B. SWOT Matrix (Strength, Weakness, Opportunity, Threat)}

After identifying the environmental analysis data of internal and external factor, the next stage is inputting the environmental factor into SWOT analysis matrix to be identified in formulating the strategies by dividing into 4 (four) strategy which is SO, WO, ST, and WT strategies, here is the following SWOT analysis of The Local Revenue Agency of Samarinda.
The Local Revenue Agency of Samarinda is in quadrant III, which means that the organization faces enormous market opportunities, but on the other hand faces several internal constraints / weaknesses as well. The focus of this strategy is to minimize the company's internal problems so that it can seize a better market. This is due to the absence of competitors. The strategic contents of the representation are as follows:

- Striving for innovation in land and building tax payments according to the Covid-19 protocol, namely by making online payments so that the safety aspects of service providers and users are carried out through the implementation of social distancing and physical distancing.

- Build a network of cooperation with various agencies and banks in land and building tax payments, in which the Local Revenue Agency of Samarinda collaborates with Pos Indonesia, Pos Giro Mobile, Kaltimtara Bank, and BPR Bank in receiving land and building tax payments by transfer.

- Improve the payment system that makes it easier for taxpayers, namely fintech, by accepting payments using gopay in the Gobills application on Gojek. Where the determination of this payment system strategy was 
taken by the Head of the Local Revenue Agency of Samarinda during the new normal era, so that there would be an increase in organizational performance in the achievement of local revenue even in the Covid-19 pandemic conditions.

\section{SPACE Matrix (Strategic Position and Action Evaluation)}

SPACE Matrix in improving the performance of the Local Revenue Agency of Samarinda is the last step after several analysis steps are conducted. This is done in three stages, namely:

- The input stage, namely by identifying and evaluating internal and external factors through IFE and EFE matrix analysis.

- Matching stage, namely through the SWOT matrix to determine strategic alternatives

- The decision stage uses the SPACE Matrix (Strategic Position and Action Evaluation) method to determine priority strategies.

According to SPACE Matrix analysis, the Local Revenue Agency of Samarinda is in Quadrant III, which reflects that the organization's performance is below average but there are still opportunities that are still open. In this position, it takes courage from the Head of the Local Revenue Agency of Samarinda to change the strategy that the organization has been carrying out so far because of the old methods which are likely outdated.

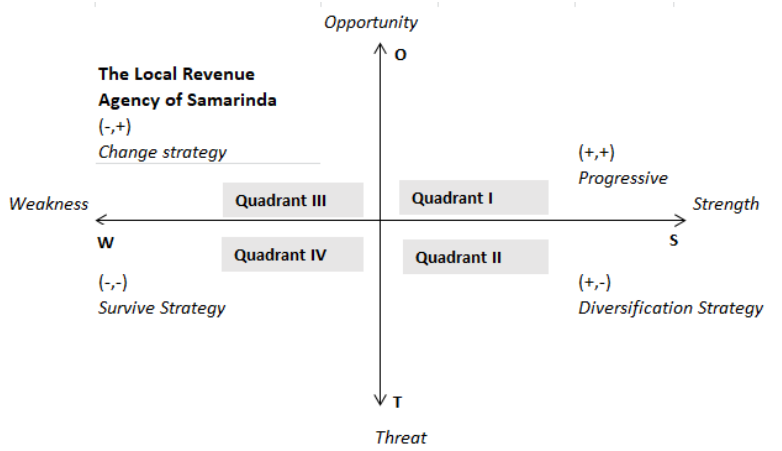

Fig. 4. SPACE matrix

This made the strategic decisions taken by the Head of the Local Revenue Agency of Samarinda to be very effective, due to changes in the conventional payment system, namely taxpayers who came to the Local Revenue Agency of Samarinda's payment counters with online payments via transfer, even during the Covid-19 Pandemic, the Head of the Local Revenue Agency of Samarinda adds to fintech payment innovations by gopay via Gobills with the Gojek application.

The decisions taken were considered very effective and efficient, because many people were familiar with the Gojek application, making it easier for people to pay land and building taxes through Gojek. This is at the same time maintaining the performance of the Local Revenue Agency of Samarinda in increasing Local Own-Source Revenue and still being able to provide excellent quality public services, but also must pay attention to the safety aspects of service providers and users through the application of social distancing and physical distance (figure 5).

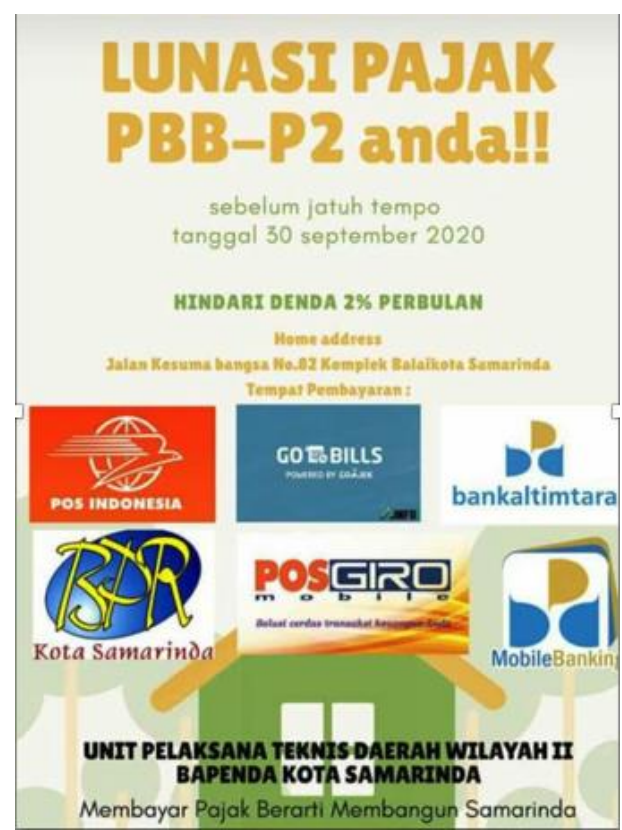

Fig. 5. Land and building taxes payment announcement.

Based on the result of this study that there is an internal and external environment that affects the change of bureaucracy in this pandemic era. So, according to the authors that the change of bureaucracy needs innovation to give public service, so there is no obstacle to serving society in this pandemic situation.

\section{CONCLUSION}

According to the result of this study, the payment of land and building tax will be effective by using an application, GoBill by GoJek, where people are still able to pay without come to the office of the Local Revenue Agency. It can be denied that this strategy is also affected by the leadership quality of the Head of the Local Revenue Agency of Samarinda who take a decision to utilize the fintech, then the local government still can achieve the local own-source revenue even int the Covid-19 pandemic conditions. The strategy comes from some analysis, internal and external factors by using SWOT matrix, Grand strategy matrix, and SPACE matrix.

\section{REFERENCES}

[1] Z. Shangguan, M.Y. Wang and W. Sun, "What caused the outbreak of COVID-19 in China: From the perspective of crisis management," Int. J. Environ. Res. Public Health, vol. 17, no. 9, 2020. 
[2] O.H. World, “Covid-19 Strategy Up Date,” no. April, p. 18, 2020.

[3] H.W. Taufik, "Birokrasi Baru Untuk New Normal: Tinjauan Model Perubahan Birokrasi Dalam Pelayanan Publik di Era Covid-19," Dialogue J. Ilmu Adm. Publik, vol. 2, no. 1, pp. 1-18, 2020.

[4] M.H. Munandar, "Analysis The Effectiveness of Tax Relaxation Due To Covid-19 Pandemy On Indonesian Economic Defense," Lex Sci. Law Rev., vol. 4, no. 1, pp. 133-142, 2020.

[5] D. Steel and I. Phillips, "How tax officials in lower-income countries can respond to the coronavirus pandemic | Overseas Development Institute (ODI)," no. April, 2020, [Online]. Available: https://www.odi.org/publications/16816-how-tax-officials-lowerincome-countries-can-respond-coronavirus-pandemic.

[6] R. Mukhtar Hakim, Strategi Peningkatan Pendapatan Asli Daerah Di Kabupaten Kepulauan Anambas. Tesis. Bogor: Institut Pertanian Bogor, 2017.

[7] Republik Indonesia, Undang-Undang No.33 Tahun 2004 Tentang Perimbangan Keuangan Antara Pemerintah Pusat dan Pemerintahan Daerah

[Online]. Available:http://eprints.uanl.mx/5481/1/1020149995.PDF.

[8] P.D.A.N.P. Pbb-p, T. Pendapatan, A. Daerah, and J. Ilmiah, "PENERIMAAN PAJAK BUMI DAN BANGUNAN," 2020.

[9] I. Hertanto and J. Sriyana, "Sumber Pendapatan Asli Daerah Kabupaten Dan Kota," J. Ekon. Stud. Pembang. (Jurusan Ekon. Pembang. Fak. Ekon. Univ. Negeri Malang), vol. 12, no. 1, pp. 76-89, 2011.
[10] P. Daerah, Lembaran daerah kota samarinda, pp. 1-41, 2011.

[11] A. Wardhono, Y. Indrawati and C.G. Qori'ah, "Kajian Pemetaan Dan Optimalisasi Potensi Pajak Dalam Rangka Meningkatkan Pendapatan Asli Daerah (Pad) Di Kabupaten Jember,” J@Ti Undip J. Tek. Ind., vol. 7, no. 2, 2013.

[12] N. Azman and F. Lena, “Optimalisasi Pemungutan Pajak Restoran,” J. Kebijak. Publik, vol. 4, pp. 119-218, 2017.

[13] F.R. David, Strategic Management: Concepts and Cases. 13th ed. South Carolina: Prentice Hall, 2011.

[14] S. Indra and Z. Rofiqoh, "Transaksi Emoney Terhadap Layanan Gopay Pada Aplikasi Gojek Perspektif Ekonomi Syariah," Al-Ahkam, vol. 15, no. 2, p. 49, 2019.

[15] Bank Indonesia, "PBI 18/40/PBI/2016 Processing of Payment Transactions," Bank Indones., p. 51, 2016, [Online]. Available: https://www.bi.go.id/id/peraturan/sistempembayaran/Pages/pbi_184016.aspx.

[16] L. Plans and P. Strategy, Scanning: Formulation: Implementation: External : Environment.

[17] T. Gürbüz, "A modified strategic position and action evaluation (SPACE) matrix method," Lect. Notes Eng. Comput. Sci., vol. 2203, pp. 866-869, 2013. 